\title{
Keberterimaan Antara Teks Sumber dan Teks Sasaran
}

\author{
Akhmad Hairul Umam \\ Universitas Tanri Abeng \\ email: ahmad.umam@tau.ac.id
}

\section{Cara Sitasi :}

Umam, A. H. (2018). Keberterimaan Antara Teks Sumber dan Teks Sasaran. Wanastra, 10(2), 47-54.

\begin{abstract}
Acceptability of the translation is one of criteria in determining the quality of translation. The objective of this research is to describe the range of acceptability between the source and target language in the novel of Vivaldi's Virgin written by Barbara Quick as well as to identify the translation procedures used by the translator. This research is translation study with descriptive qualitative method. While the data of research are sentences taken from both the source text and the target text containing word, phrase and sentence. From the assessment, it can be concluded that translator is capable enough to translate the sentences from the source text into the target text. A translation can be understood as a transfer of massage from one language to another. Translation is an attempt to convert from one form to another to retransmit messages from the source text to the target text. Finding of this study shows that 164 data taken randomly 110 (67\%) are acceptable, 33 (20\%) less acceptable, and 21 (13\%) unacceptable.
\end{abstract}

Keywords: Acceptability, Target Language, And Source Language.

\section{PENDAHULUAN}

Bahasa dan budaya adalah dua hal yang tidak bisa dipisahkan dan keduanya mempengaruhi penerjemahan. Sebagaimana dikatakan oleh Newmark dalam Silalahi (2009) 'no language, no culture', artinya bahasa tidak terpisahkan dari budaya para penuturnya (Simatupang, 2000). Bahasa sebagai sistem yang terstruktur (Structure system) sama halnya dengan sistem lain memiliki pola yang umumnya bersifat statis (Machali, 2000). Dengan demikian, untuk menghasilkan terjemahan yang baik perlu menguasai budaya bahasa sumber dan sasaran. Hal ini sejalan dengan apa yang diungkapkan oleh Witte (1994), "They have to be biculturally competent".

Pentingnya seorang penerjemah memahami budaya dikarenakan teks merupakan suatu hasil tindak komunikasi dengan pembaca, norma, budaya, dan sebagainya yang berlainan (Machali, 2000). Setiap terjemahan baik harfiah ataupun bukan adalah hasil analisis pengalihan dan penyerasian yang disesuaikan dengan tindak komunikasi. Oleh karena itu penerjamahan teks yang berkaitan dengan unsur budaya harus dilakukan dengan seksama sehingga tidak menimbulkan perspektif dan makna yang berbeda.

Bahasa sebagai sistem bunyi bersifat manasuka (arbitrar) disusun secara manasuka pula sehingga timbul kata yang membawa makna tertentu. Mengingat sifat bahasa yang manasuka, maka tidak ada hubungan antara kata dan benda yang diwakilinya dan orang bebas memberi nama kepada benda dan situasi yang ditemuinya. Sementara dalam ilmu semiotik yang diperkenalkan oleh Ferdinand de Saussure dijelaskan bahwa sistem tanda: signified dan signifier atau signifie dan significant bersifat atomistis. Makna muncul saat ada hubungan yang bersifat asosiasi atau in absentia antara "yang ditandai' (signified) dan 'yang menandai' (signifier). Oleh karena itu tanda adalah kesatuan dari suatu bentuk penanda (signifier) dengan sebuah ide atau petanda (signified). Dengan kata lain, penanda adalah "bunyi yang bermakna" atau "coretan yang bermakna". Jadi, penanda adalah aspek material dari bahasa yaitu apa yang dikatakan atau didengar dan apa yang ditulis atau dibaca. Petanda adalah gambaran mental, pikiran, atau konsep. Jadi, petanda adalah aspek mental dari bahasa (Bertens, 2001).

Setidaknya ada tiga aspek penilaian dalam menentukan kualitas suatu terjemahan yaitu keakuratan (accuracy), keberterimaan (acceptability) dan keterbacaan (readibility). Keakuratan berkaitan dengan kesepadanan makna antara Bahasa Sumber (BSu) dan Bahasa Sasaran (BSa). Pesan yang disampaiakan harus akurat, sama makna. Kesepadanan makna di sini bukan hanya sekedar bentuknya tetapi pesan, ide gagasan pada BSu tersampaikan pada BSa. Kesepadanan ini juga bukan berarti penerjemahan kata perkata, melainkan keseluruhan ide atau pesan. Ketepatan di sini bermakna bahwa terjemahan yang berkualitas adalah terjemahan yang menyampaikan informasi atau 
pesan dari BSu secara benar, tepat, dan jujur sesuai dengan maksud dari pengarang BSu. Informasi yang disampaikan tidak ada yang tertinggal, tidak ada yang bertambah, dan tidak ada yang berbeda. Pembaca dapat memahami hasil karya terjemahan itu dengan mudah serta sesuai dengan pesan yang terkandung didalamya.

Aspek keberteriamaan adalah erat kaitannya dengan derajat kewajaran suatu teks terjemahan terhadap norma, kaidah dan budaya BSa. Terjemahan yang memiliki tingkat keberteriaman tinggi menghasilkan terjemahan yang alamiah, luwes dan tidak kaku. Sementetara aspek keterbacaan dalam penilaian suatu terjemahan berkaitan dengan mudah tidaknya suatu teks terjemahan dapat dipahami. Tingkat keterbacaan yang tinggi diukur apabila suatu teks terjemahan bisa dipahami dan dimengerti oleh pembaca BSa. Biasanya faktor-faktor yang mempengaruhi keterbacaan antara lain panjang ratarata kalimat, jumlah kata-kata baru, dan kompleksitas gramatika dari bahasa yang digunakan. Ketiganya; keakuratan, keberterimaan dan keterbacaan- mempunyai peranan penting dalam menentukan kualitas suatu terjemahan. Ketiga aspek penilaian kualitas terjemahan tersebut dikenalkan oleh Nababan (2006).

Keberterimaan hasil terjemahan adalah suatu proses yang berhubungan dengan kemampuan untuk memindahkan makna dari suatu bahasa ke bahasa lain. Keberterimaan dalam penerjemahan merupakan hal penting untuk menghasilkan terjemahan yang baik. Makna yang ada dalam teks sumber harus bisa diterima saat diterjemahkan ke teks sasaran baik dalam tataran makna ataupun juga dalam tataran bentuknya. Idealnya sebelum melakukan penerjemahan, seorang penerjemah perlu mengetahui untuk siapa (audience design) dan untuk tujuan apa (needs analysis) dia menerjemahkan. Proses ini merupakan salah satu tahapan yang tidak dapat diabaikan dalam melakukan penerjemahan sehingga dia bisa menentukan metode, prosedur dan ideologi penerjemahan yang akan digunakan.

Konsep penerjemahan dapat dipahami sebagai reproduksi pesan yang tekandung dalam $\mathrm{BSu}$. Hoed (2006) mengutip pernyataan Basnett dan Lefevere menyatakan bahwa apapun tujuannya, setiap reproduksi selalu dibayangi oleh ideologi tertentu. Ideologi dalam penerjemahan adalah prinsip atau keyakinan tentang betul-salah dan baik-buruk dalam penerjemahan, yakni terjemahan seperti apa yang terbaik bagi masyarakat pembaca $\mathrm{BSa}$ atau terjemahan seperti apa yang cocok dan disukai masyarakat tersebut.

Sementara instrumen keberterimaan (acceptability) terjemahan dapat dijelaskan dalam tabel berikut ini:

Tabel 1. Instrumen Tingkat Keberterimaan

\begin{tabular}{|c|c|c|}
\hline Skala & Definisi & Kesimpulan \\
\hline 3 & $\begin{array}{l}\text { Terjemahan terasa alamiah; } \\
\text { istilah teknis yang } \\
\text { digunakan dalam novel } \\
\text { akrab bagi pembaca: kata, } \\
\text { frasa, klausa, dan kalimat } \\
\text { yang digunakan sudah } \\
\text { sesuai dengan kaidah- } \\
\text { kaidah bahasa Indonesia }\end{array}$ & Berterima \\
\hline 2 & $\begin{array}{l}\text { Pada umumnya terjemahan } \\
\text { sudah terasa alamiah; } \\
\text { namun ada sedikit } \\
\text { masalah pada penggunaan } \\
\text { istilah teknis atau terjadi } \\
\text { sedikit } \\
\text { gramatikal. }\end{array}$ & $\begin{array}{l}\text { Kurang } \\
\text { Berterima }\end{array}$ \\
\hline 1 & $\begin{array}{l}\text { Terjemahan tidak alamiah } \\
\text { atau terasa seperti karya } \\
\text { terjemahan; istilah teknis } \\
\text { yang digunakan tidak } \\
\text { berterima }\end{array}$ & $\begin{array}{l}\text { Tidak } \\
\text { Berterima }\end{array}$ \\
\hline
\end{tabular}

Sumber: Nababan (2004) dengan modifikasi

Keberterimaan mengarah pada kelaziman dan kealamiahan teks terjemahan dalam $\mathrm{BSa}$ sesuai dengan kaidah dan norma kebahasaan pembaca BSa. Teks tersebut harus dapat diterima dan dipahami maksudnya oleh pembaca sasaran. Pembaca akan memahami makna yang terkandung dalam kalimatkalimat yang membentuk suatu teks terjemahan dan kemudian mengaitkannya dengan konteks situasi teks tersebut. Istilah keberterimaan (acceptability) ini juga digunakan untuk menyatakan ketaatan terjemahan pada aturan linguistik dan norma tekstual bahasa sasaran. Toury memberikan gagasan bahwa suatu terjemahan akan menjadi adequate jika norma yang diikuti berasal dari budaya dan bahasa sumber, sedangkan terjemahan tersebut disebut berterima (acceptable) jika norma yang diikuti berasal dari budaya dan bahasa sasaran (Munday, 2001).

\section{METODOLOGI PENELITIAN}

Penelitian ini menggunakan metodologi kualitatif dengan menganalisa ungkapan bahasa Inggris dan terjemahannya lalu dianalisis berdasarkan tingkat keberterimaan antara teks sumber dan teks sasaran. Penelitian ini termasuk penelitian kualitatif deskriptif dengan menggunakan teknik mencari data, mengumpulkan, dan menganalisisnya. Data yang dikumpulkan berwujud kata-kata dalam kalimat atau gambar yang mempunyai arti lebih dari sekedar angka atau jumlah (Sutopo, 2002). Sementara data dalam penelitian ini berupa kata-kata yang diambil secara acak dalam sebuah novel Vivaldi's Virgins 
karya Barbara Quick yang diterbitkan oleh HarperCollin Publishers 2007.

Teknis penelitian ini dilakukan dengan tiga tahap. Pertama membaca referensi dan hasil penelitian yang terkait untuk mempertajam pemahaman penulis tentang konsep penerjemahan. Kedua menganalisa teks dengan melihat tingkat keberterimaan antara Tsu dan Tsa. Ketiga menyampaikan hasil penelitian terkait temuan yang menjadi fokus pembahasan.

Sementara instrumen dalam penelitian ini adalah peneliti sendiri dengan berusaha memahami teks sebaik-baiknya, mengumpulkan data, mengolah data dan menganalisa data. Peneliti juga menggunakan kamus linguistik dan kamus besar bahasa Indonesia untuk memberikan gambaran yang tepat tentang makna antara teks sumber dan teks sasaran. Adapun pengujiannya didasarkan pada hasil penelitian dengan kajian pustaka, ketekunan pengamatan, dan pencatatan.

\section{HASIL DAN PEMBAHASAN}

Setelah membandingkan dan menganalisis teks sumber dan teks sasaran pada novel Vivaldi's Virgin, secara keseluruhan data hasil terjemahan ini dinilai mempunyai tingkat keberterimaan yang tinggi. Berdasarkan data sampling dari 164 data, terdapat 110 data $(67 \%)$ kategori berterima, 33 (20\%) kurang berterima, dan 21 (13\%) tidak berterima. Dengan demikian, penelitian ini menyimpulkan bahwa terjemahan ini mengindikasikan bahwa sebagian besar teks terjemahan sudah berterima dan teks terjemahannya terasa alamiah dan pembaca mudah memahaminya. Hasil penilaian tingkat keberterimaan terjemahan ini secara keseluruhan dapat dilihat pada grafik 1 berikut ini.

\section{Grafik 1. Keberterimaan Terjemahan}

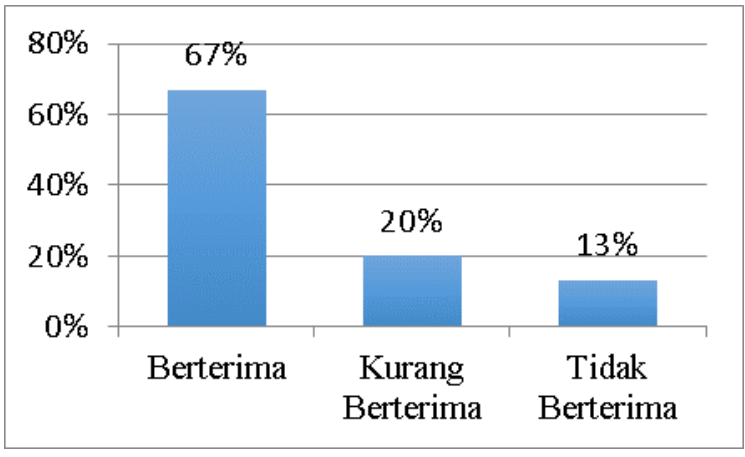

\section{Terjemahan Berterima}

Suatu terjemahan dikatakan berterima apabila suatu teks terjemahan tersebut terasa alamiah, istilah teknis yang digunakan lazim digunakan dan akrab bagi pembaca, kata, frasa, klausa, dan kalimat yang digunakan sudah sesuai dengan kaidah-kaidah bahasa Indonesia. Diantara contoh keberterimaan penerjemahan antara $\mathrm{TSu}$ dan $\mathrm{TSa}$ ini dapat dijelaskan di bawah ini:

Tabel 2. Terjemahan Berterima

\begin{tabular}{|c|c|c|}
\hline No & Teks Sumber & Teks Sasaran \\
\hline 1 & $\begin{array}{l}\text { I shouted at her. } \\
\text { "I wash my hands } \\
\text { of you"! And with } \\
\text { that, I turned my } \\
\text { back and ran } \\
\text { farther into the } \\
\text { forest. }(P .118)\end{array}$ & $\begin{array}{lr}\text { Aku } & \text { berteriak } \\
\text { kepadanya. "Aku tak } \\
\text { ikut campur dalam } \\
\text { masalahmu"! Setelah } \\
\text { itu aku membalikkan } \\
\text { punggungku dan berlari } \\
\text { jauh menuju hutan. (P. } \\
\text { 119) }\end{array}$ \\
\hline 2 & $\begin{array}{l}\text { La Befana added, } \\
\text { as if the words } \\
\text { tasted of bile, } \\
\text { "kissing her } \\
\text { lover!" (P. 206). }\end{array}$ & $\begin{array}{l}\text { La } \\
\text { menambahkan, } \\
\text { kata-kata yang seolah } \\
\text { terasa empedu, "sedang } \\
\text { mencium kekasihnya," } \\
\text { (P. 203). }\end{array}$ \\
\hline
\end{tabular}

\section{Penjelasan Tabel 2. Contoh Kalimat Nomor 1}

Frasa 'wash my hand' yang terdapat dalam tabel 2 pada contoh 1 mempunyai penerjemahan yang berterima dalam TSa. Keberterimaan tersebut disebabkan oleh adanya kesesuaian makna antara frasa 'wash my hand' apabila dibandingkan dengan konteks kalimat tersebut. Frasa 'wash my hand' dalam kalimat contoh di atas mengandung makna figuratif, bukan makna harfiah. Ungkapan metafora semacam ini juga dikenal dalam Tsa sehingga pembaca mudah memahami makna dari teks terjemahan tersebut. Pembaca untuk memahami pesan dari ungkapan metafora ini tidak perlu memahami konteks penyusun dari kalimat ini.

Sebagai unsur bahasa yang memiliki makna figuratif, frasa 'wash my hand': 'tak ikut campur masalahmu' dikenali sebagai citra metafora, kata frasa ini digunakan untuk menggambarkan topik metafora tersebut, atas dasar kemiripan yang dimiliki oleh frasa 'wash my hand 'dengan topik metafora yaitu kata ganti ' $I$ ' yang mengacu pada Maria del Violin. Kalimat 'I wash my hand' jika diterjemahkan secara harfiah menjadi 'saya mencuci tangan' adalah ungakapan figuratif dengan maksud metaforanya 'Tak ikut campur masalahmu'. Pemadanan kalimat metafora ini merupakan sikap pelepasan dan pelarian dari rasa tanggungjawab dari suatu masalah yang sedang dihadapi.

Ungkapan metafora pada contoh (1) di atas memperoleh terjemahan berupa metafora juga dalam Tsa dengan citra yang berbeda 'wash my hand' 
diterjemahkan menjadi 'tidak ikut campur dalam masalahmu'. Topik metafora ini tidak disebutkan secara eksplisit sedangkan citranya adalah 'wash my hand'. Penerjemahan metafora Tsu menjadi metafora dengan citra dan tipe perbandingan yang sama dalam Tsa dapat menghasilkan terjemahan yang sepadan.

Sementara prosedur penerjemahan teks metafora di atas, ditemukan modulasi berupa penggeseran sudut pandang, struktur kalimat TSu yang mempunyai makna positif menjadi negatif dan modulasi bebas. Frasa 'wash my hand' yang secara harfiah 'mencuci tangan' diterjemahkan menjadi 'tidak iku campur dalam masalahmu'. Pada TSa terdapat eksplisitasi berupa kata 'masalahmu' yang tidak ada dalam TSu dengan tujuan untuk memberikan penegasan dan kewajaran dalam bahasa sasaran.

\section{Penjelasan Tabel 2. Contoh Kalimat Nomor 2}

Ungkapan frasa 'words tested of bile': kata-kata terasa empedu, yang terdapat dalam contoh (2) di atas mendapatkan terjemahan yang berterima. Kata 'words', pada pada konteks kalimat di atas mengacu perkataan La Befana yang sama sekali tidak ada kaitannya dengan empedu. Dengan demikian, kalimat di atas mengandung makna figuratif bukan makna harfiah.

Sebagai ungkapan kebahasaan yang mengandung makna figuratif, kalimat di atas memperlihatkan perbandingan yang eksplisit berupa simile. Perbandingan ini dapat dijelaskan dengan menguraikan unsur-unsur penyusun metafora menjadi topik, citra dan titik kemiripan. Topik dari metafora di atas adalah 'words': kata-kata. Citra metafora simile ini adalah 'bile': empedu. Titik kemiripan antara topik dan citra disebutkan secara eksplisit berupa perumpamaan yang seperti 'empedu'. Perumpamaan semacam ini adalah ungkapan yang terasa sulit diutarakan dan diekspresikan karena mengangdung makna yang pahit baik bagi penutur ataupun pendengarnya. Kesusahan untuk mengungkapkan kata ini sama halnya dengan rasa empedu yang sangat pahit.

Metafora bentuk simile pada contoh 2 di atas memperoleh terjemahan berupa simile juga dengan citra yang sama dan eksplisitasi simile berupa 'as if': seolah. Perbandingan antara topik: 'as if words': kata-kata dan citranya 'of bile: seolah terasa empedu dalam Tsa dieksplisitkan dengan menambahkan kata 'seolah'. Titik kemiripan antara topik dan citra tetap dibiarkan eksplisit dalam Tsu.

Penerjemahan metafora bentuk simile di atas menjadi simile dengan menggunakan citra yang sama dapat menghasilkan terjemahan yang sepadan. Pembaca Bsa dapat memahami pesan yang terdapat dalam simile seperti pembaca Tsu memahami metafora sumbernya dalam Tsu. Penambahan kata 'seolah terasa' di antara topik dan citra metafora tersebut memperjelas pesan yang hendak disampaikan, yakni perasaan sulit untuk mengungkapkan kata-kata bagi La Befana. Adapun konteks tempat simile tersebut, juga membantu pembaca Bsa memahami pesan yang terdapat dalam simile yang menjadi terjemahan Tsu.

Sementara dilihat dari prosedur penerjemahannya, penerjemahan simile menjadi simile merupakan modulasi yaitu modulasi bebas berupa eksplisitasi perbandingan melalui penggunaan kata 'seolah'. Selain itu, juga ditemukan prosedur transposisi yang mengakibatkan penggeseran intrasistem dan penggeseran unit, yaitu pada penerjemahan 'tested of bile' menjadi 'terasa empedu'. Preposisi 'of' dalam Tsa memperoleh padanan zero. Penggeseran ini disebabkan oleh kekurangwajaran penggunaan nominal dengan preposisi 'dari' sebagai terjemahan 'of' dalam Tsa. Sehingga 'tested of bile' tidak diterjemahkan menjadi 'terasa dari empedu' melainkan 'terasa empedu'.

\section{Terjemahan Kurang Berterima}

Terjemahan kurang berterima merujuk pada terjemahan yang pada umumnya sudah terasa alamiah, namun ada sedikit masalah pada penggunaan istilah teknis atau terjadi sedikit kesalahan gramatikal. Terjemahan dianggap kurang berterima apabila bahasa yang digunakan pada terjemahan kurang sesuai dengan aturan bahasa sasaran, pilihan kata kurang memasyarakat dan kurang dikenali, serta ada kata atau istilah yang kurang wajar. Terdapat sebanyak 33 data yang tergolong sebagai terjemahan yang kurang berterima, diantaranya:

Tabel 3. Terjemahan Kurang Berterima

\begin{tabular}{llll}
\hline No & Teks Sumber & Teks Sasaran \\
\hline 1 & Not yet-the old & Belum, jangan \\
bat will be & sekarang, r sang \\
& watching from the & kelelawar tua itu masih \\
& window until we & terus mengawasi kita \\
& reach & the & hingga kita sampai di \\
embankment. & tapal batas bangunan \\
& (P.40) & ini. (Hlm. 41) \\
\hline 2 & "Must I write it in & Pastor! Haruskah aku \\
& my own blood, & menulis lagu ini dengan \\
& Padre, or will you & darahku sendiri? Atau \\
& lend me some & kamu akan \\
& ink" (P. 249) & meminjamkan pena? \\
& & (Hlm. 247)
\end{tabular}




\section{Penjelasan Tabel 3. Contoh Kalimat Nomor 1}

Sebagai ungkapan kebahasaan yang mengandung makna figuratif, kalimat contoh 1 di atas dapat dikenali sebagai metafora karena kalimat tersebut memperlihatkan perbandingan yang implisit, yang merupakan esensi dari sebuah metafora. Perbandingan itu dapat dijelaskan dengan menguraikan unsur-unsur penyusun metafora sebagai berikut. Topik yang dibicarakan dalam metafora di atas adalah tersembunyi yang bisa dikenali dengan melihat konteks kalimat sebelumnya yang berupa Matteo. Sedangkan citranya 'old bat'. Jadi Matteo dibandingkan dengan 'old bat' atas dasar kemiripan tertentu. Titik kemiripan tersebut tidak disebutkan secara eksplisit.

Apabila memperhatikan konteks kata kelelawar tua, titik kemiripan dapat dijelaskan sebagai berikut. Kelelawar adalah sejenis binatang yang mempunyai dua sayaf besar yang dikonotasikan dengan sorban dan kelelawar tidak bisa berjalan cepat, hal ini digambarkan dengan sosok Matteo yang jalannya tertatih-tatih.

Penerjemahan ungkapan metafora di atas memperoleh terjemahan berbentuk metafora juga dengan citra yang sama. Namun terjemahan tersebut dikategorikan kurang berterima yang penyebabnya terletak pada pengulangan/penambahan kata yang semakna. Kata 'jangan sekarang' setelah kata 'Belum' sebenarnya tidak perlu dimunculkan karena artinya sudah jelas. Penambahan kata ini oleh penerjemah justru membuat kalimat tidak efektif. Bisa jadi maksud penerjemahan adalah dengan tujuan menciptakan ungkapan yang wajar berdasarkan asumsi atau penafsiran konteks lain dalam TSu yang sebenanrya tidak perlu dilakukan.

Sementera dari segi prosedur penerjemahan, metafora tersebut mengalami transposisi berupa penggeseran struktur dari DM (the old bat) menjadi MD (sang kelelawar itu) dan penggeseran kelas. Pada contoh 2 di atas artikel 'the' yang merupakan artikel takrif diterjemahkan menjadi 'itu' yang dalam Bsa tergolong pronominal penunjuk. Penggeseran ini disebabkan karena dalam Bsa tdak terdapat takrif untuk menggantikan 'the'. Perubahan baik penggeseran struktur dan kelas ini merupakan suatu tuntutan yang berlaku dalam kaidah Bsa.

\section{Penjelasan Tabel 3. Contoh Kalimat Nomor 2}

Kalimat pada contoh 2 merupakan ungkapan kiasan yang samasekali bukan menggambarkan makna sebenarya yaitu menulis dengan 'darahku sendiri'. Dengan demikian, frasa 'my own blood' itu tidak memiliki makna harfiah tetapi makna figuratif. Frasa 'my own blood' merupakan citra metafora yang digunakan untuk menggambarkan unsur lain, yaitu topik metafora itu. Hubungan antara 'my own blood' dengan topik yang dijelaskannya merupakan sebuah perbandingan. Pada contoh 2 di atas, topik metaforanya tidak dinyatakan secara eksplisit. Akan tetapi, dengan menelusuri konteksnya dapat diketahui bahwa topik yang dibicarakan dalam metafora itu adalah seorang penyair yang bernama Libretto. Pembaca Bsu memahami metafora dengan citra 'my own blood'; darahku tersebut sebagai ungkapan untuk menunjukkan sikap kekesalan pada orang lain dengan cara melebih-lebihkan yang sebenarnya kalau dilakukan tidak mungkin bisa dilakukan. Ungkapan ini muncul dari sang Penyair lantaran tidak adanya alat lain yang bisa digunakan untuk bisa menulis lagu.

Penyebab terjemahan tersebut dikategorikan kurang berterima adalah terletak pada kesalahan teknis pada pemberian tanda baca kalau dilihat TSa setelah kata 'Pastor' penerjemah memberikan tanda seru (!) sementara dalam Tsu hanya berupa tanda baca 'koma'. Penerjemah terlalu berorientasi pada TSa untuk menciptakan ungkapan yang wajar berdasarkan asumsi atau penafsiran konteks lain dalam TSu yang sebenanrya tidak perlu dilakukan.

Dilihat dari segi prosedur penerjemahannya, citra tersebut mengalami modulasi yang berupa implisitasi dan tranposisi yaitu penggeseran struktur. Artikel 'in' dalam bahasa Tsa mempunyai padanan zero sedangkan frase ' $m y$ own blood' yang bestruktur MD dalam Tsu menjadi DM dalam Tsa. Implisitasi artikel 'in' dalam Tsa bertujuan untuk menjadikan kalimat menjadi ungkapan yang wajar. Adapun penggeseran struktur pada penerjemahan contoh (2) di atas merupakan penggeseran wajib dan otomatis yang disebabkan karena tuntutan kaidah Bsa.

\section{Tejermahan Tidak Berterima}

Terjemahan tidak berterima identik dengan terjemahan tidak alamiah atau terasa seperti karya terjemahan; istilah teknis yang digunakan tidak lazim digunakan dan tidak akrab bagi pembaca, kata, frasa, klausa, dan kalimat yang digunakan tidak sesuai dengan kaidah-kaidah bahasa Indonesia. Pada umumnya ketidakberterimaan terjemahan yang tedapat BSa disebabkan oleh ketidakhadiran subjek atau predikat kalimat atau klausa, ketidakhadiran klausa utama dan penggunaan istilah yang tidak lazim. Dari 164 data, terjemahan yang tidak berterima terdapat 21 data terjemahan dianggap tidak berterima.

Tabel 4. Terjemahan Tidak Berterima

No Teks Sumber Teks Sasaran




\begin{tabular}{lllr}
\hline 1 & $\begin{array}{l}\text { It put me in mind } \\
\text { of flames of Hell } \\
\text { (P.3) }\end{array}$ & $\begin{array}{l}\text { Rambutnya nampak } \\
\text { seperti kobaran api } \\
\text { neraka (Hlm. 3) }\end{array}$ \\
\hline 2 & With my arms & Dengan seluruh jiwaku \\
& wrapped around yang & telah \\
my music and & membungkus musik \\
music wrapped & dan & musik \\
around my heart, & membungkus hatiku, \\
I knew that I aku tahu selain musik \\
would want for tak ada lagi yang aku \\
nothing. (P. 236) & inginkan di dunia ini.
\end{tabular}

(Hlm. 233)

\section{Penjelasan Tabel 4. Contoh Kalimat Nomor 1}

Sebagai ungkapan kebahasaan yang mengandung makna figuratif, kalimat contoh (1) di atas dapat dikenali sebagai metafora karena kalimat tersebut memperlihatkan perbandingan yang implisit yang merupakan esensi dari metafora. Perbandingan ini dapat dijelaskan dengan menguraikan unsur-unsur penyusun metafora tersebut sebagai berikut. Topik yang dibicarakan dalam metafora di atas adalah ' $I t$ ' (kata ganti yang mengacu pada rambut Don Antonio Vivaldi) sedangkan citranya adalah 'flame of Hell': kobaran api neraka. Titik kemiripan dari ungkapan metafora ini disebutkan secara eksplisit dalam kalimat sebelumnya yaitu 'frightened me': 'menakutkan saya'. Citra metafora berupa 'kobaran api' ini menunjukkan suatu kesan jika rambut Vivaldi tidak tersisir secara rapi, warnanya merah tua mirip api dan membuat siapapun yang melihatnya akan berpikiran negatif bahkan cenderung takut seperti halnya api neraka yang digambarkan dengan sesuatu yang menakutkan.

Titik kemiripan dari metafora ini dapat dilihat dari kalimat teks setelahnya yaitu rambut yang dimiliki oleh Don Antonio Vivaldi berwarna merah dan membuat para siswa merasa takut. Dan pada kalimat berikutnya juga diperjelas dengan kalimat: bahwa suaranya yang terdengar tidak sabar menggambarkan kalau Vivaldi bukanlah orang yang memiliki kasih sayang terhadap ana-anak.

Metafora pada contoh (1) di atas memperoleh terjemahan berupa simile yang ditandai dengan pengeksplisitan perbandingan antara topik dan citra melalui penggunaan kata seperti. Citra yang sama yaitu 'kobaran api neraka' tetap digunakan dalam bentuk terjemahannya. Tipe perbandingan simile dalam Tsa sama dengan tipe perbandingan metafora Tsu yaitu perbandingan dengan titik kemiripan yang eksplisit. Penerjemahan metafora Tsu menjadi simile dalam Tsa merupakan salah satu cara untuk mencapai terjemahan yang sepadan. Pesan yang terdapat dalam metafora contoh (1) di atas dapat dipahami oleh pembaca Tsa sebagaimana pembaca
Tsu dengan melihat konteks yang ada di kalimat sebelumnya yaitu 'frightened me': menakutkan saya. Konotasi 'api neraka' jelas menunjukkan makna negatif dan sangat menakutkan bagi setiap orang yang mendengar dan melihatnya.

Kalimat 'it put me in mind' oleh penerjemah dalam Tsa diterjemahkan menjadi 'rambutnya nampak' yang jika ditelusuri dalam Tsu tidak ditemukan padanannya. Jika diperhatikan terjemahan tersebut hanya berupa klausa. Dengan kata lain tidak muncul klausa utama sehingga informasi yang disampaikan belum lengkap. Padahal pembaca berhak mengetahui informasi yang dihilangkan tersebut. Penghilangan boleh dilakukan dalam penerjemahan namun tidak menghilangkan informasi atau pesan Tsu. Penghilangan lazim dilakukan pada hal-hal yang bukan substansial dari teks yang diterjemahkan. Sementara penyebab terjemahan tersebut dikategorikan tidak berterima karena ungkapan tersebut hanya berupa klausa dan tidak ada klausa utama akibatnya informasi yang disampaikan tidak lengkap. Hal ini juga disebabkan ketidakhadiran subjek atau predikat, klausa atau kalimat.

Penerjemahan melakukan penambahan kata dengan tujuan menciptakan ungkapan yang wajar berdasarkan asumsi atau penafsiran konteks lain dalam TSu yang sebenanrya tidak perlu dilakukan. Pada kalimat sesudahnya, ditemukan tranposisi yang berupa penggeseran intrasistem, preposisi 'of' pada frasa 'frame of Hell' dalam Tsa diterjemahkan menjadi zero. Penggeseran ini dilakukan karena tuntutan struktur dan kaidah Bsa. Dalam Bsa terasa kurang wajar jika frasa tersebut diterjemahkan menjadi 'lidah dari neraka'.

Sementera dari segi prosedur penerjemahannya, metafora tersebut di atas mengalami penggeseran sudut pandang dan modulasi bebas berupa eksplisitasi perbandingan dengan menggunakan kata 'seperti' sekaligus mengubah bentuk metafora menjadi simile

\section{Penjelasan Tabel 4. Contoh Kalimat Nomor 2}

Frasa 'wrapped around' tidak berterima secara harfiah. Ketidakbeterimaan tersebut disebabkan oleh adanya ketidaksesuaian semantis diantara unsur-unsur penyusun kalimat dilihat dari konteks pembentukannya. Ketidaksesuaian semantis itu dapat dijelaskan sebagai barikut.

Kata 'wrapped around', pada pada konteks kalimat di atas merupakan citra dari 'arm': jiwa yang telah membungkus. Secara harfiah, kata 'membungkus musik' tidak tepat penggunaannya. Dengan demikian, kalimat di atas mengandung makna figuratif, bukan makna harfiah. Sebagai kalimat yang mengandung makna figuratif 
kalimat tersebut memperlihatkan perbandingan yang implisit, sehingga dapat digolongkan ke dalam metafora. Perbandingan ini dapat dilihat dengan jelas dengan menguraikan unsur-unsur penyusun metafora itu, yaitu topik, citra dan titik kemiripannya.

Topik metafora itu adalah 'arms': jiwa sedangkan citranya adalah 'wrapped oround': membungkus. Titik kemiripan antara topik dan citra tidak disebutkan secara eksplisit. Akan tetapi dengan menelusuri konteksnya dapat diketahui bahwa titik kemiripan antara topik dan citra pada metafora sebelumnya adalah penyatuan yang sangat dalam sehingga sukar untuk dipisahkan. Konteks dalam ungkapan kal imat tersebut menjelaskan bahwa Anna Maria del Violin terlihat tertutup untuk menyukai orang lain selain musik yang telah menjadi bagian dari hidupnya. Musik bagi dia, tidak hanya sebagai kesenangan tapi juga teman pendamping yang bisa menghibur jiwa dan raganya.

Bentuk terjemahan metafora di atas memperoleh terjemahan yang berupa metafora juga, dengan citra yang beda yaitu 'arms' yang secara harfiah: tangan mendapatkan terjemahan menjadi: 'jiwa'. Ketidakcocokan kolokasi dan tipe perbandingan metafora terjemahan dalam Tsa juga sama dengan ketidakcocokan kolokasi dan tipe perbandingan metafora Tsu, yaitu ketidakcocokan kolokasi tersembunyi dengan titik kemiripan implisit.

Sementara penyebab terjemahan tersebut dikategorikan tidak berterima terletak pada penggunaan istilah 'membungkus' yang terasa tidak alamiah bagi pembaca TSa. Kata 'membungkus' tidak umum apabila digunakan untuk disandingkan dengan kata 'jiwa' dan 'musik'. Seharusnya, kata 'wraped around' tidak diterjemahkan secara kata perkata (semantis) yang membuat hasil terjemahannya kurang wajar. Sebagai alternatif dapat digantaikan dengan 'menyelimuti jiwaku' dari pada 'membungkus jiwaku. Pergantian kata ini membuat ungkapan teraasa lebih wajar dan muda dipahami oleh pembaca.

Sementara dilihat dari segi prosedur penerjemahan, dalam metafora Tsu ke dalam Tsa terjadi prosedur modulasi bebas. Modulasi bebas yang berupa penggeseran sudut pandang. Kata 'arms' secara harfiah 'tangan', oleh penerjemah dalam Tsa diterjemahkan menjadi 'jiwa' yang jika ditelusuri dalam Tsu tidak ditemukan padanannya. Akan tetapi, konsep tersebut ada dalam Tsu dan dieksplisitkan dalam Tsa dengan tujuan menciptakan ungkapan kalimat yang wajar. Titik kemiripan dalam contoh di atas tidak disebutkan dengan jelas. Dengan demikian, penerjemahan ini dapat digolongkan dengan kolokasi tersembunyi

\section{KESIMPULAN}

Berdasarkan analisa terhadap keberterimaan antara teks sumber dan teks sasaran pada terjemahan novel Vivaldi's Virgin, peneliti menemukan tingkat keberterimaan teks tersebut terbilang tinggi dengan indikasi teks terjamahan dalam bahasa sasaran (BSa) terasa alamiah dan wajar sehingga pembaca mudah memahami dari pesan yang tertulis dalam novel tersebut. Tingkat perbandingannya berdasarkan data sampling dari 164 data, terdapat 110 data $(67 \%)$ kategori berterima, 33 (20\%) kurang berterima, dan $21(13 \%)$ tidak berterima.

Secara umum, peneliti mengamati terjemahan dikategorikan kurang berterima dan tidak berterima cenderung disebabkan oleh penggunaan kalimat yang tidak gramatikal, kesalahan ketik, dan penggunaan istilah asing yang tampaknya belum akrab bagi pembaca, kolokasi yang tidak tepat, kata bahasa Indonesia yang belum lazim bagi pembaca.

Terjemahan yang baik dan berkualitas biasanya dihasilkan oleh penerjemah yang memiliki kompetensi kebahasaan, tekstual, bidang ilmu, dan budaya. Secara keseluruhan, penerjemahan uangkapan dalam novel ini baik dalam kata, frasa dan kalimat Tsu ke dalam Tsa sudah mencapai keberterimaan yang cukup tinggi. Dengan kata lain sudah terdapat kesesuaian. Hampir semua teks bahasa sumber diterjemahkan menjadi terjemahan yang berterima dalam bahasa sasarannya. Meskipun ada beberapa kalimat dalam bentuk metafora dalam bahasa sumbernya diterjemahkan menjadi kalimat yang bukan metafora dalam bahasa sasarannya, tetapi itu sangat sedikit. Sebaliknya ada juga kalimat dalam bentuk metafora dalam bahasa sumber yang tidak diterjemahkan menjadi metafora dalam bahasa sasarannya. Penerjemah telah menggunakan metode yang sesuai dengan jenis teks novel yaitu metode semantis dengan mengedepankan keterbacaan dan keberterimaan pada teks sasaran.

\section{REFERENSI}

Bertens, K. 2001. Filsafat Barat Kontemporer. Jakarta: Gramedia Pustaka Utama.

Eugene A. Nida, and Charles R. Taber.1974. The Theory and Practice of Translation. Leiden: E.J. Brill, 1974.

Hoed. B.H, Tresnati S.S dan Rochayah M.1993. "Pengetahuan Dasar tentang Terjemahan" Lintas Bahasa No.1: 1-35 Jakarta: Pusat Penerjemahan FSUI.

Hornby, AS. 2007. Oxford advanced Learners' Dictionary of Current English. London: Oxford University Press. Walton Street. 
Kridalaksana, Harimurti. 1993. Kamus Linguistik. Jakarta: Gramedia Pustaka Utama

Machali, Rochayah.1998. Redefining Textual Equivalence in Translation with Special Reference to Indonesian-English. Jakarta: Pusat Penerjemahan Universitas Indonesia.

Machali, R.2000. Pedoman Bagi Penerjemah. Jakarta: Grasindo

M.R. Nababan, 2008. Equivalence in Translation: Some Problem-Solving Strategies, 2008. (Diunduh dari: Proz.com Translation Article Knowledge)

Newmark, P.1981. Approach to Translation. Oxford: Pergamon Press

Simatupang, Maurits. 2000. Pengantar Teori Penerjemahan. Jakarta: Depdiknas

Silahahi, Roswita. 2009. Dampak Teknik, Metode, dan Ideologi Penerjemahan pada Kualitas Terjemahan Teks Medical-Surgical Nursing Dalam Bahasa Indonesia. Medan: Disertasi Universitas Sumatera Utara.

Quick, Barbara, 2007. Vivaldi's Virgins, HarperCollin Publishers .

Witte, H. 1994. "Translation as a means for a better understanding between cultures" In Dollerup, C. and Lingegaard, A. (eds.). Teaching Translation and Interpretating 2. Insights, Aims, Visions. Amsterdam: John Benjamins, 69-75.

\section{PROFIL PENULIS}

Akhmad Hairul Umam, M.Hum. Menyelesaikan Program Strata Satu (S1) Pendidikan Bahasa Inggris UIN Syarif Hidayatullah Jakarta 2004. Pendidikan Magiste (S2) Linguistik Terapan diselesaikan di Universitas Negeri Jakarta 2010. Aktif mengikuti seminar dan menulis opini di Koran Pelita \& Detik.Com. Saat ini menjadi kandidat doktor bidang Linguistik Terapan Bahasa Inggris di Universitas Katolik Amajaya. 